\title{
Analysis if the factors affecting exchange rate variability in Pakistan.
}

\author{
Raja Sher Ali Khan \\ Department of Business \& Economics Foundation University Islamabad
}

\section{INTRODUCTION}

Most of the analyst, economist and policymakers have favoredfloating exchange rate system over fixed exchange rates because floating exchange rate absorbs the variations in foreign markets in a better way in the existence of an efficient market of foreign exchange.There are certain variables that have an effect on the exchange rate such factors are inflation, interest rate, growth, imports, exports and oil prices.Central Bank needs to assure that such factors are controlled and it has a strict control over the foreign exchange market and Banks.Pakistan is a small economy involved in foreign trade. The currency of Pakistan is Rupee, which has depreciated a great deal since the independence of Pakistan in August 1947, as a result of which Pakistani exports become expensive in the international market and lost the competitiveness and imports became inexpensive due to which the balance of trade got affected. As a result State Bank of Pakistan delinked the rupee from dollar and adopted a manage float system in 1982.From 2000 onwards SBP has used different mechanisms and tried to stabilize the exchange rate. These efforts have helped in stabilizing the exchange rate in from 2000 to 2008 but still fluctuations were also there and in the recent years the exchange rate has become volatile(Mahmood et al, 2011). The volatility of the exchange rates can have an adverse effect on the economy.To understand the exchange rate behavior the variable affecting the exchange rate needs to be studied.

\section{RATIONALE OF THE STUDY}

Exchange rate is a key element that needs to be addressed specially in Pakistan where Pakistani rupee is consistently losing its value and it is very necessary to look into those factors that are affecting the exchange rate in Pakistan. In the current economic condition it is very important to analyze these factors and see which of these needs to be taken care off to control the exchange rate. This research can contribute in the policy making and implementation of the policies like monetary, fiscal and trade policy. The results can provide a guideline for the authorities to look at those factors that are causing this variability in exchange rate and it can contribute in the body of knowledge and it has its importance in the context of Pakistan as in this recent time where exchange rate variability is very high the need to study the main factors causing this variability is very much there.

\section{PROBLEM STATEMENT}

Which are the factors that affect exchange rate variability in a developing country like Pakistan?

\section{OBJECTIVES OF THE STUDY}

To examine the factors affecting the volatility in exchange rates in Pakistan.

To identify the extent to which these factors are affecting the volatility in exchange rates in Pakistan.

\section{SIGNIFICANCE OF THE STUDY}

The research will contribute to the body of knowledge by filling in the gap in knowledge especially in recent Pakistani context as recommendations will be useful for the investors, Foreign MNCs, Forex market players, Government, companies from all sectors,exporters and importers. Thus, research can contribute to the economy and policy making as it identifies the relations and their significance between macroeconomic variables and exchange rate variability.

\section{LITERATURE REVIEW INFLATION}

Monetary policy and other tools like fiscal policy are used to keep a check on inflation and its impacts on the other macroeconomic variables like exchange rate especially in economies that are emerging. (Ho \& McCauley, 2003). Inflation has its effects on all major macroeconomic variables including the exchange rate.There is a significant and long term effect on exchange rate of monetary and inflationary shocks. Monetary policy has its implication on the exchange rate as it controls the inflation.(Choudhri\&Hakura, 2006). Inflation in Pakistan is continuously increasing and the growth of the country is affected by it. A simple inflation model is used and the period in which inflation was high in Pakistan the growth was low, showing that the inflation has proved harmful for the economic growth of Pakistan in the past years. The state bank of Pakistan should control the money supply by implementing a monetary policy that can reduce the inflation to the target set for inflation during the year as it affects the whole economy. (Khan \&Schimmelpfennig, 2006). The countries that control inflation have seen a decline in exchange rates but with such monetary policy the exchange rate variability has 
increased. (Edwards, 2006). Inflation affects all macroeconomic variables like trade, growth and exchange rate. There should be a tight monetary policy to control the inflation and its impact on the economic variables like growth and exchange rate. (Jilani et al, 2010). For a country like Pakistan the inflation must be brought to a single digit level so that it cannot affect the economic growth and other macroeconomic variables like exchange rate. (Hussain\& Malik, 2011). As the inflation increases the local currency depreciates and exchange rate increases due to which the imports bills increase and economic progress is hampered. (Khattak et al, 2012). In Asian economies the exchange rate is more volatile as compared to in developed economies. There is no swap between inflation and output in Asia but in developed countries as inflation increases the output decreases.(Sek et al, 2012). Monetary policy plays a vital role in controlling the inflation and by which controlling the variations in exchange rate. (Baljinnyam\& LU, 2013).

\section{INTEREST RATE}

Pakistan rupee is continuously losing its value against the US dollar due to which the economy is suffering. A traditional flow model has been used.If the Pakistani authorities want to make Pakistani rupee strong as against other currencies of industrial regimes they must reduce inflation and raise the interest rate to a desired level and monetary policy can be used in changing the exchange rate. (Bhatti, 2001). The likely level of output and interest rate are the main purposes of the monetary policy that regulate the inflation and exchange rate. Thus the monetary policy uses the interest rate and targets the domestic and CPI inflation to control the exchange rate.(Gali\&Monacelli, 2002). In 1990`s the Japanese economy had a close to zero interest rates and due to which the inflation targeting and exchange rate movements were affected greatly. In Japan these zero bounds caused losses in output and due to low interest rate the liquidity increased to a level that takes to a liquidity trap. Monetary policy still proves effective due to the control over exchange rate but this effect is very small as interest rate is close to zero. So to manage exchange rate Japan must increase the interest rate and control the liquidity.(Coenen\& Wieland, 2003). Rise in interest rate makes the exchange rate stronger and limits the pressure of inflation. (Sanchez, 2005).Appreciation is observed in currencies that are with rising interest rate and depreciation is seen in lower interest rate currencies. So carry trade and interest rate changes play a significant role in affecting the exchange rate. (Cavallo, 2006). In both developing and developed countries the central bank or the state bank stabilizes the economy and enhances the growth by using the monetary policy and other policy tools. Changes in the interest rate have major impact on market rate of lending and borrowing and this can affect the monetary policy measure of the government and has an impact on market forces. (fazal\&salam, 2013)

\section{OIL PRICES}

Oil prices affect the exchange rate in oil exporting countries but still their currencies do not show that much instability as compared to small economies that are mostly oil importing,because they have effective legal and organized system that manage and control the exchange rate. Due to the effective and favorable features of their institutions, the exchange rates of countries like Norway, Canada and Saudi Arabia do not react strongly with the changes in oil prices. (Rickne, 2009). World economy is greatly affected by the Oil as it is one of the most crucial and important physical commodity. Countries make interventions in oil markets so that they can evade the adverse effects of volatility in oil prices. Oil importing countries like Indonesia must make efforts to reduce dependency on oil by going for alternative sources of energy. Due to its influence on other macroeconomic variables like exchange rate, countries must predict its movements and react to the changes in oil prices through effective policy making. The Dubai market can be used as a benchmark to predict the oil prices. (Kuncoro, 2011). Countries that are oil rich and are oil exporters have benefited from the high international prices of oil and their real exchange rate has appreciated significantly due to which other sectors that are not based on resources become less competitive. As it results in a shift in factor of production the future growth and employment in these countries become doubtful as oil is depleted. So oil richness is not the source for long term economic growth and the exchange rate appreciation or overvaluation is also linked with the high economic growth. (Trevino, 2011). The correlation has become stronger recently for oil and for industrial metal also. Therefore it can be concluded that the exchange rate absorbs the changes in the oil price in euro countries and other economies linked to euro area including Czech Republic. (Novotny, 2012). Exchange rate and basic macroeconomic variables have a stable long run relationship especially in emerging economies.Policies should not take into consideration the oil price shocks in determining the exchange rate but normal oil price movements can predict the exchange rate. (Kucuk, 2012). The predictive power of exchange rate is strong but it depends upon the sample showing that the oil prices have a strong effect on exchange rate. (Ferraro et al, 2012). Due to this rise in oil prices inflation and other economic variables are also affected and the stock market is also affected by the increase in inflation. (Ansar\&Asghar, 2013). 


\section{IMPORTS}

There is a dynamic relationship between imports, income and exchange rate. ADRL approach was used and showed that as real income increasesin Pakistan, the demand for imported products from countries like UK, USA, Germany and Japan increases due to which the imports increase because of this the exchange rate is affected as there is a significant relationship between imports and exchange rate. (Alam\& Ahmed, 2011). The variations in exchange rate have its implications on the whole economy including the financial intermediaries, individual investors and corporate investors. Exchange rate variability affects the profits of companies. The companies that are heavily dependent on imports will suffer from the business and conversion losses because high imports will depreciate the local currency as imports and exchange rate are significantly related and imports is one of the main factors that affects the exchange rate variability. (Kisaka\&Mwasaru, 2012). Macroeconomic variables like trade, growth and inflation are also cointegrated with exchange rate policy. The exchange rate of the countries that are oil importing like Pakistan is greatly affected by its imports. (Sattar, 2012). Devaluation of rupee has a negative effect on the Pakistan economy. The local currency depreciates with any increase in exchange rate. The import and export demand in Pakistan is less elastic due to which exchange rate is negatively affected as investors keep on Importing and Pakistan is also an oil importing country. Authorities in Pakistan must try to make such policies through which exchange rate is kept at lower level. (Abbas, 2013).

\section{EXPORTS}

The exports are one of the main sources of correcting the negative balance of payment. The relationship between exports and exchange rate is there but exchange rate does not affect the exports directly and exchange rate affects the income of the people and which have an effect on the exports (Smith, 2009). It is usually said that exchange rate instability reduces the amount of export but it is evident from that amount of trade may not necessarily be affected by the exchange rate volatility but volatility can change the structure of the trade. Exports and exchange rate have negative relationship so countries trying to keep their exchange rate at a lower level must boost their exports otherwise exchange rate volatility can them dependent on a fewer goods when deciding the systems of exchange rate. (Alvarez et al, 2009). The volatility in exchange rate has been taken as a factor that affects the trade.Real exports demand, export prices and exchange rate volatility are related with each other. Exports of India, Pakistan and Sri Lanka are affected negatively by the volatile exchange rate. The exports are the main source of increasing the foreign exchange reserves in developing economies and with high exports the exchange rate can be brought down. Policies must be made to control the volatility in exchange rate so that exports continue to increase and exchange rate is kept under control or desirable level. (Mukhtar\& Malik, 2010). Exchange rate, imports and exports are related to each other. A change in export affects the exchange rate volatility. The exchange rate policy of Pakistan has reduced the exports and the overvalued exchange rate has increased the imports rather than exports. Overvalued exchange rate affects the macroeconomic stability of the country and high exports would have stabilized the exchange rate volatility. (Ahmed et al, 2010). Uncertainty in exchange rate can affect the growth of trade. For a country like Pakistan whose exchange rate is very volatile its trade with US, UK and UAE is affected by the uncertainty in its exchange rate. The regression results show that there is a relationship between the trade growth and exchange rate uncertainty. State Bank needs to intervene and control the volatility of the exchange rate. This uncertainty can be reduced by increasing the exports so that the exchange rate can be controlled. (Hassan, 2013)

\section{EXCHANGE RATE VARIABILITY}

Fluctuations and variability in exchange rate affect the growth and trade. So to control the exchange rate variability, macroeconomic variables needs to be managed through policies and other economic measures.(ozturk, 2006). The policies should be designed in a way to reduce variability in exchange rate by influencing the macroeconomic factors like inflation and interest rate. (Hayakawa \& Kimura, 2008). Policymakers must use the monetary policy as a tool to reduce the changes in macroeconomic variables so that the exchange rate can be controlled as variations in exchange rate have an adverse effect on the economy. (Zakeria\&Ghauri, 2011). Time varying probabilities approach is used and results show that inflation and exchange rate are significantly related as inflation increases the local currency depreciates and as imports increase the exchange rate also increase while export reduces the uncertainty and with high exports the exchange rate goes down as inflation also reduces.(Khemiri\& Ali, 2012). The exchange rate importance can never be underestimated as exchange rate has its effect on the economy.Investors need to clearly identify the exchange rate movements before investing in stocks. So the study of those factors that directly affect the exchange rate variability is also of great importance. Policies should be made that reduce the exchange rate variability. (Khan et al, 2012). The economic and non-economicelements play a vital role in the determination of exchange rate. (Saeed et al, 2012). Frequent and small changes in local and international economic variables 
cause volatility in exchange rate and variability increases because of these changes.Investor's decisions, openness of the economy, interest rate, inflation and wealth are such factors that can affect the exchange rate. It is recommended that exchange rate volatility is reduced and exchange rate is kept at a competitive level. (Haider et al, 2012)

\section{RESEARCH METHODOLOGY}

Secondary data is used to conduct this research. Monthly data from May 2006 to April 2013 is collected from different sources like economic survey of Pakistan, ministry of commerce and trade, ministry of finance, Pakistan bureau of statistics, state bank of Pakistan, IMF and various related financial websites like brecorder, trending economics andonada.com. Consumer price index (CPI) is used for inflation and its monthly data has been collected from the economic survey of Pakistan. KIBOR is used for interest rate and its monthly data has been collected from state bank of Pakistan. Monthly data of Oil prices in dollar per barrel have been collected from various websites including IMF, brecorder and OPEC. The monthly data of imports and exports have been collected from the Pakistan bureau of statistics. The data for GDP for the years has been collected from the economic survey of Pakistan. The daily exchange rates have been collected from the website of onada.com of historical exchange rateand brecorder.Exchange rate data has been collected at daily frequency in order to calculate the variability for each month.

Independent variables include Inflation, interest rate, oil price, import and exports and exchange rate variability is the dependent variable. CPI has been used for inflation, KIBOR has been used for interest rate, natural log of oil prices Rupees per barrel has been used for oil prices, import and export have been used as a percentage of GDP as used by (tschetter, 2008) and (Haque\& Kemal, 2007) and exchange rate variability using range as a measure to calculate variability for each month as used by (Parsley \& Wei, 2000) and it has been used as the dependent variable. To further strengthen the analysis and its reliability standard deviation has also been used as a measure of variability and results have been drawn using both range and standard deviation as measure of exchange rate variability.

In order to analyze the factors affecting the exchange rate variability a simple linear regression model has been used that explains the effect of one variable on the other and its significance.

$\mathrm{Y}=\alpha+\beta 1(\mathrm{INF})+\beta 2(\mathrm{INT})+\beta 3(\mathrm{OP})+\beta 4(\mathrm{EXP})+\beta 5(\mathrm{IMP})$

Where $\mathrm{Y}$ is exchange rate variability, INF is inflation, INT is interest rate, OP is oil prices, EXP is exports, and IMP is imports

To further analyze the variables and investigate their relation correlation has been found which tells about the relationship and the strength of the relationship between the variables. Regression analysis and correlation have been used as the analytical tools required for the analysis of the factors affecting the exchange rate variability.

Following hypotheses have been developed in the light of above discussion and review

H1: There is a significant relationship between Inflation in Pakistan and Exchange rate variability.

$\mathrm{H} 2$ : There is asignificant relationship between interest rate in Pakistan and Exchange rate variability.

H3: There is asignificant relationship between oil prices in Pakistan and Exchange rate variability.

H4: There is a significant relationship between Imports of Pakistan and Exchange rate variability.

H5: There is a significant relationship between Exports of Pakistan and Exchange rate variability.

V. RESULTS AND DISCUSSION

Table 1 Model Summary

\begin{tabular}{|l|l|l|l|l|}
\hline L \\
\hline Model & R & R Square & Adjusted R Square & Std. Error of the Estimate \\
\hline 1 & $.787 a$ & .619 & .595 & .7011787 \\
\hline a. Predictors: (Constant), IMP, OP, INF, XP, INT \\
\hline
\end{tabular}

In the above table the coefficient of determination $\mathrm{R}^{2}$ is 0.619 which shows that $61.9 \%$ of the variation in exchange rate variability is explained by inflation, interest rate, oil prices, imports and exports. In the above table the value of Adjusted $\mathrm{R}^{2}$ is 0.595 which shows that $59.5 \%$ of the variation in exchange rate variability that is dependent variable is likely to be explained by the independent variables that are inflation, interest rate, oil prices, imports and exports.

Table 2

ANOVAa 
Analysis if the factors affecting exchange rate variability in Pakistan.

\begin{tabular}{|c|c|c|c|c|c|}
\hline Model & Sum of Squares & Df & Mean Square & $\mathbf{F}$ & Sig. \\
\hline Regression & 62.375 & 5 & 12.475 & 25.374 & $.000 b$ \\
\hline Residual & 38.349 & 78 & .492 & & \\
\hline Total & 100.724 & 83 & & & \\
\hline \multicolumn{6}{|c|}{ a. Dependent Variable: EXY } \\
\hline b. Predictors: & Constant), IMP, & & XP, INT & & \\
\hline
\end{tabular}

The level of significance used in this modelis 0.05 . The $f$ Value is 25.37 and the $\mathrm{p}$ value is $0.000<0.05$. So the distribution is $\mathrm{f}$ ( 5 and 78 ), and the probability of observing a higher value or equal to 0.000 is lesser than 0.05.The value of $\mathrm{F}, \mathrm{P}$ and coefficient of determination show that the model is fit and good one.

\begin{tabular}{|c|c|c|c|c|c|}
\hline \multicolumn{6}{|c|}{ Table 3 Coefficients } \\
\hline \multirow[t]{2}{*}{ Model } & \multicolumn{2}{|c|}{ Unstandardized Coefficients } & \multirow{2}{*}{$\begin{array}{c}\text { Standardized Coefficients } \\
\text { Beta }\end{array}$} & \multirow[t]{2}{*}{$\mathbf{t}$} & \multirow[t]{2}{*}{ Sig. } \\
\hline & B & Std. Error & & & \\
\hline (Constant) & -9.843 & 1.917 & & -5.136 & .000 \\
\hline INF & .194 & .024 & .864 & 8.004 & .000 \\
\hline INT & -.235 & .074 & -.362 & -3.160 & .002 \\
\hline $\mathbf{O P}$ & 1.423 & .220 & .477 & 6.454 & .000 \\
\hline $\mathbf{X P}$ & -35.255 & 73.395 & -.052 & -.480 & .632 \\
\hline IMP & -17.787 & 39.143 & -.055 & -.454 & .651 \\
\hline \multicolumn{6}{|c|}{ a. Dependent Variable: EXY } \\
\hline
\end{tabular}

In the table thevalues of $\mathrm{t}$ statistics are suggesting that inflation has a positive significant effect on the exchange rate variability thus rejecting the null hypothesis and accepting the alternate hypothesis. Interest rate has a positive significant effect on the exchange rate variability thus rejecting the null hypothesis and accepting the alternate hypothesis. Oil price has a positive significant effect on the exchange rate variability thus rejecting the null hypothesis and accepting the alternate hypothesis. Imports and exports have an insignificant effect on the exchange rate variability and the Null hypothesis is accepted. Therefore there is no significant relationship between imports and exports of Pakistan and exchange rate variability.

From above coefficients table the regression equation for the research model is:

$\mathrm{Y}=-9.843+0.194 \mathrm{INF}-0.235 \mathrm{INT}+1.423 \mathrm{OP}-35.255 \mathrm{EXP}-17.787 \mathrm{IMP}$

The results for the correlation are given by the following table.

\begin{tabular}{|c|c|c|c|c|c|c|c|}
\hline \multicolumn{8}{|c|}{ TABLE 4 Correlations } \\
\hline & & INF & INT & OP & $\mathrm{XP}$ & IMP & EXY \\
\hline \multirow[t]{3}{*}{ INF } & Pearson Correlation & 1 & $.661 * *$ & .027 & -.008 & .102 & $.633 * *$ \\
\hline & Sig. (2-tailed) & & .000 & .811 & .944 & .355 & .000 \\
\hline & $\mathrm{N}$ & 84 & 84 & 84 & 84 & 84 & 84 \\
\hline \multirow[t]{3}{*}{ INT } & Pearson Correlation & $.661 * *$ & 1 & $.243 *$ & -.113 & $-.259 *$ & $.345 * *$ \\
\hline & Sig. (2-tailed) & .000 & & .026 & .308 & .017 & .001 \\
\hline & $\mathrm{N}$ & 84 & 84 & 84 & 84 & 84 & 84 \\
\hline \multirow[t]{3}{*}{$\mathrm{OP}$} & Pearson Correlation & .027 & $.243 *$ & 1 & -.016 & -.036 & $.415 * *$ \\
\hline & Sig. (2-tailed) & .811 & .026 & & .887 & .744 & .000 \\
\hline & $\mathrm{N}$ & 84 & 84 & 84 & 84 & 84 & 84 \\
\hline \multirow[t]{3}{*}{$\mathrm{XP}$} & Pearson Correlation & -.008 & -.113 & -.016 & 1 & $.731 * *$ & -.065 \\
\hline & Sig. (2-tailed) & .944 & .308 & .887 & & .000 & .554 \\
\hline & $\mathrm{N}$ & 84 & 84 & 84 & 84 & 84 & 84 \\
\hline \multirow[t]{3}{*}{ IMP } & Pearson Correlation & .102 & $-.259 *$ & -.036 & $.731 * *$ & 1 & .072 \\
\hline & Sig. (2-tailed) & .355 & .017 & .744 & .000 & & .514 \\
\hline & $\mathrm{N}$ & 84 & 84 & 84 & 84 & 84 & 84 \\
\hline \multirow[t]{3}{*}{ EXY } & Pearson Correlation & $.633 * *$ & $.345 * *$ & $.415^{* *}$ & -.065 & .072 & 1 \\
\hline & Sig. (2-tailed) & .000 & .001 & .000 & .554 & .514 & \\
\hline & $\mathrm{N}$ & 84 & 84 & 84 & 84 & 84 & 84 \\
\hline
\end{tabular}


The table4shows that there is correlation between inflation and exchange rate variability. The correlation coefficient for inflation with exchange rate variability is .633 at the significance level of $0.000<0.01$. The correlation is significant at 0.01 level. This shows that inflation contributes to $63.3 \%$ of exchange rate variability. There is correlation between interest rate and exchange rate variability. The correlation coefficient for interest rate with exchange rate variability is 0.345 at the significance level of $0.002<0.01$. The correlation is significant at 0.01 level. This shows that interest rate contributes to $34.5 \%$ of exchange rate variability. So it can be concluded that interest rate and exchange rate variability are correlated but the correlation is not that strong as compare to that between inflation and exchange rate variability. There is correlation between oil prices and exchange rate variability. The correlation coefficient for oil prices with exchange rate variability is .415 at the significance level of $0.000<0.01$. The correlation is significant at 0.01 level. This shows that oil price contributes to $41.5 \%$ of exchange rate variability. So it can be concluded that oil price and exchange rate variability are correlated but the correlation is normal and it is greater than the correlation between interest rate and exchange rate variability but it is less than the correlation between inflation and exchange rate variability. There is no correlation between imports and exports and exchange rate variability. The correlation coefficient for imports with exchange rate variability is .072 at the significance level of $0.514>0.01$. The correlation is insignificant at 0.01 level. So it can be concluded that imports and exports and exchange rate variability are not correlated.

\section{CONCLUSION}

After conducting an analysis of the factors affecting the exchange rate variability in Pakistan it can be said that the inflation in Pakistan is the factor that affects the exchange rate variability the most in the recent years. As inflation increases the money supply increases and local currency depreciates due to which the exchange rate changes and variability increases. Oil prices have been found as the second most influential factor that affects the exchange rate variability in Pakistan.Being an oil importing country Pakistan makes heavy oil payments in foreign currency affecting the exchange rate variability as due to these payments the whole economy suffers. Interest rate also has a negative effect on the exchange rate variability and investors will invest in the country where interest rate is high so as the interest rate increases the exchange rate variability decreases but this effect is not as significant as that of inflation and oil prices. It has been found that the trade has not affected the variability of exchange rate in the recent years as imports and exports have an insignificant effect on the exchange rate variability in Pakistan.Other than the factors used for the research there are certain factors that affect the exchange rate and can possibly significantly affect the exchange rate variability. Government intervention is among one of those factor that can have an effect on the exchange rate variability. Foreign remittances and transaction with the IMF and USAID can also affect the exchange rate variability.

\section{RECOMMENDATIONS}

As inflation has been found as the most influential factor affecting the exchange rate efforts must be made by the government to control inflation. The government must stop printing excessive money for its needs as because of this money supply increases and inflation is caused in the economy.

As the oil prices have been found as the second factor that affect the exchange rate the most so being an oil importing country Pakistan must reduce its dependence on the oil to reduce the variability in exchange rate.New energy resources like coal, bio gas andLPG should be used to reduce dependence on oil so that the effect of oil prices on exchange rate can be reduced.Interest rate is the major source of controlling the inflation and through this exchange rate variability can be reduced. An efficient and robust monetary policy can reduce the exchange rate variability in the country.Fiscal policy and monetary policy should be made with the consideration for their effects on the exchange rate variability. Foreign trade and openness of the economy should be increased to bring prosperity in the country. The government should intervene to make exchange rate stable whenever there is high variability in the exchange rate.Policy makers must keep into consideration the exchange rate variability before making policies that affect the exchange rate.

\section{REFERENCES}

[1]. Abbas,M. (2013). Effect of trade deficit on economy of Pakistan, Interdisciplinaryjournal of contemporary research in business, Vol 4, No. 11, 2013, pp. 176-215.

[2]. Alam, S. \& Ahmed, Q. (2011). Exchange rate volatility and Pakistan`s bilateral imports from major sources: An application of ADRL approach, international journal of economic and finance, Vol 3, No.2, May 2011, pp.246-254.

[3]. Baljinnyam, B. \& Lu, d. (2013). Analysis on influencing factors of the exchange rate between Chinese Yuan (CNY) and Mongolian Tögrög (MNT), International Journal of Development and Sustainability, Volume 2 Number 3 (2013).

[4]. Bhatti, R. (2001). Determining Pak rupee exchange rate vis-à-vis six currencies of the industrial world: some evidence based on traditional flow model, the Pakistan development review, 40 : 4 Part II (Winter 2001) pp. 885-897.

[5]. Cavallo, M. (2006). Interest rate, carry trades and exchange rate movements, FRBSF economic letter, number 2006-31, November 2006.

[6]. Choudhri, E. \&Hakura, D. (2006). Exchange rate pass through to domestic prices: Does the inflationary environment matter, journal of international money and finance, Vol. 25 (2006), pp. 614-639. 
[7]. Coenen, G. \& Wieland, V. (2003). The zero interest rate bound and the role of exchange rate for monetary policy in Japan, ECB working paper series, WP No. 218, March 2003.

[8]. Edwards, S. (2006). The relationship between exchange rate and inflation targeting revisited, NBER working paper no. 12163, April 2006, JEL NO. F-02, F-43.

[9]. Ferraro, D., Rogoff, k. \& Rossi, B. (2012).Can Oil Prices Forecast Exchange Rates?Duke University ICREA-UPF, BGSE, CREI,October 21, 2012.

[10]. Gali, J. \&Monacelli, T. (2002). Monetary policy and exchange rate volatility in small open economies, NBER working paper, WP 8905, April 2002.

[11]. Haque, N. \& Kemal, M. (2007). Impact of export subsidies on Pakistan exports, Pakistan Institute Development Economics papers, WP/07/26, number 26, pp.1-18, 2007.

[12]. Haider, S., Ullah, S. \&Azim, P. (2012). Impact of exchange rate volatility on foreign direct investment: A case study of Pakistan, Pakistan economic and social review,Volume 50, No. 2 (Winter 2012), pp. 121-138.

[13]. Hassan, M. (2013). Volatility of exchange rate affecting the trade growth: A case of Pakistan with US, UK and UAE, European scientific journal, vol. 9, No. 22

[14]. Hayakawa, K. \& Kimura, F. (2008). The effect of exchange rate volatility on international trade in East Asia, ERIA working paper series, WP. 03, December 2008.

[15]. Ho, C. \& McCauley, R. (2003). Living with the flexible exchange rate: issues and recent experience in inflation targeting emerging market economies, BIS working paper, WP No. 130, February 2003.

[16]. Hussain, S. \& Malik, S. (2011). Inflation and Economic Growth: Evidence from Pakistan, international Journal of economic and finance, Vol. 3, No.5; October 2011.

[17]. Jilani, S., Cheema, F. \&Asim, M. (2010). exploring impacts of macroeconomic variables on GDP of Pakistan, journal of management and social sciences, Vol. 6, No. 2, (Fall 2010) 65-73.

[18]. Khattak, N., Tariq, M. \& khan, J. (2012). Factors Affecting the Nominal Exchange Rate of Pakistan: An Econometric Investigation (1982-2008), Asian Economic and Financial Review Vol. 2, No. 2, pp. 421-428.

[19]. Khemiri, R. \& Ali, M. (2012). Exchange rate pass through inflation dynamics in Tunisia: A markov-switching approach, Economics open assessment E-journal, Vol. 39, August 2012.

[20]. Kisaka, S. \&Mwasaru, A. (2012). The causal relationship between exchange rate and stock prices in Kenya, research journal of finance and accounting, Vol.3, No.7, 2012, pp. 121-130.

[21]. Kucuk, N. (2012). Nonlinear real exchange rate dynamics and oil prices in commonwealth of independent states, International conference of Euro Asian economies, session 3-A, PP.60-67.

[22]. Kuncoro, H. (2011). The volatility of world crude oil prices, economic journal of emerging markets, Vol. 3(1), April 2011, pp.115 .

[23]. Mahmood, I., Ullah, E. \&Ahmed, H. (2011). Exchange rate volatility and macroeconomic variables in Pakistan, business management dynamics, Vol.1, No.2, August 2011, pp. 11-22.

[24]. Mukhtar, T. \& Malik, S. (2010). Exchange rate volatility and export growth: evidence from selected South Asian Countries, SPOUDAI, Vol. 60, No.3-4, (2010), University of Piraeus, pp. 58-68.

[25]. Novotny, F. (2012). The link between the brent crude oil price and the Dollar exchange rate, Prague economic papers, vol 2, 2012, pp. 220-232.

[26]. Parsley, D. \& Wei, S. (2000). Explaining the border effect: the role of exchange rate variability, shipping cost and geography, NBER paper, WP/8909/2000.

[27]. Rickne, J. (2009). Oil Prices and Real Exchange Rate Movements in Oil-Exporting Countries: The Role of Institutions, IFN working paper NO. 810, 2009.

[28]. Saeed, A., Awan, R., Sial, M. \&Sher, F. (2012). An Econometric Analysis of Determinants of Exchange Rate in Pakistan, International Journal of Business and Social Sciences, vol.3 NO. 6, special issue, March 2012.

[29]. Sanchez, M. (2005). The link between interest rate and exchange rate: Do contractionary depreciation makes a difference? , European central bank, working paper series no. 548, November 2005.

[30]. Sattar, R. \& Rehman, H. (2012). Effectiveness of Exchange Rate in Pakistan: Causality Analysis,Pak. J. Commer. Soc. Sci.2012 Vol. 6 (1), 83-96.

[31]. Sek, S., Ooi, C. \& Ismail, M. (2012). Investigating the relationship between exchange rate and inflation targeting, Applied mathematical sciences, Vol.6,2012, no.32, pp. 1571-1583.

[32]. Smith, M. (2009). Impact of exchange rate on export volumes, reserve bank of New Zealand Bulletin, Vol. 67, No. 1, September 2009 , pp. 5-13.

[33]. Trevino, J. (2011). Oil prices and the real exchange rate appreciation: Is there Dutch disease in CEMAC, International monetary fund paper, WP/11/268, number 268, (2011)

[34]. Zakeria, M. \&Ghauri, A. (2011). Trade openness and real exchange rate: Evidence from Pakistan, The Romanian economic journal, Vol. XIV, No. 39, March 2011, pp. 201-229. 